\title{
Mapping of Agriculture Knowledge Information System for Betel Vine Growers
}

\author{
Manaranjan Biswas ${ }^{1}$ and Anindita Saha ${ }^{2 *}$
}

\author{
${ }^{1}$ Krishnagar Collegiate School, Krishnanagar, Nadia, West Bengal (741 101), India \\ ${ }^{2}$ Dept. of Agricultural Extension, Palli Siksha Bhavana (Institute of Agriculture), Visva -Bharati, Sriniketan, \\ West Bengal (731 236), India
}

\author{
Corresponding Author \\ Anindita Saha \\ e-mail: anindita_psb@rediffmail.com
}

\author{
Article History \\ Article ID: IJEP0387 \\ Received in $19^{\text {th }}$ September, 2020 \\ Received in revised form $08^{\text {th }}$ November, 2020 \\ Accepted in final form $23^{\text {rd }}$ November, 2020
}

\begin{abstract}
Studying Agriculture Knowledge Information System (AKIS) in terms of generation, dissemination, transformation, utilization, storage and retrieval of knowledge and information is needed for Agriculture development. Study was conducted in purposively selected Nadia district of West Bengal. Betel vine growers, extentionists and researchers were considered as respondents. Information obtained from all the actors of AKIS was summarized in matrix from to analyze the extent of information exchange among various actors pertaining to cultural practices, plant protection techniques and harvesting of betel vine cultivation. The matrix revealed that information flow was linear in majority of the cases. The feedback got blocked with some of the actors, as upstream flow of information was weak. The present study was undertaken to study the existing Farmer-Extensionists-Researcher linkage as perceived by the linkage matrix with AKIS. A total of 200 farmers responding Karimpur 1, Karimpur 2, Krishnaganj and Chakdah block of Nadia district were selected for the study. The district and blocks were selected purposively for the study. Farmers were selected by the simple random sampling method. The result of the study reveal that betel growers had low linkage with researcher and were found maximum linkage with extension workers like Assistant Director of Agriculture, Krishi Projukti Sohaok, Opinion leaders, Dealers etc.
\end{abstract}

Keywords: Agriculture knowledge information system, linkage, matrix

\section{Introduction}

The present age has been rightly called as an Information Age. Information has become the most important element for progress in society. According to Kemp "information has been described as the fifth need of man ranking after air, water, food and shelter". Everyone needs information about everything even in his day to day life. In agriculture environment, relevant and timely information helps farming community to take right decision to sustain growth of agricultural activity. Use of information in agriculture sector is enhancing farming productivity in a number of ways. Providing information on weather trends, best practice in farming, timely access to market information helps farmer make correct decisions about what crops to plants and where to sell their product and buy inputs (Bachhav, 2012). Information adoption among farming community is widely acknowledged as one of the critical factors for efficient and effective agricultural decision-making (Cash, 2001; Galloway and Mochrie, 2005; Rao, 2006). Constraints existing in interface between generations transfer and use of farm innovation should be removed through the dual concept of synergy and agricultural knowledge and information system (Saha, 2001). However, present orientations, such as farming system research (FSR) and Training and Visit (T\&V) extension are unable to achieve synergy as they are centralized, default to wealthier rural elites, do not build farmer capacity and ignore informal elements. Hence, system management and knowledge system will be required to hold all formal and informal elements together, coordinate interactions build concerns and monitor outcomes of synergy. AKIS in term of generation, dissemination, transformation, utilization, storage and retrieval of knowledge and information is needed for agricultural development. Hence, the management of AKIS interfaces for institutionalization of integrated links among research, extension and education as well as among other elements with the farming community is an imperative task. The betel vine farmers are in dire need of improved cultivation technologies to increase production and to better off their living standard. This can be healed up by integrating education, research and extension, as the isolation of researchers from farmers and extension workers hinders easy observation of the direct results and relevance of research. Keeping these in view, an attempt was made to analyze who contributes 
which kind of knowledge and information to decision making in dairying and what are the relationship between different actors to map AKIS with respect to betel vine growers.

\section{Materials and Methods}

The study was conducted in purposively selected Nadia district of West Bengal. Multi-stage stratified sampling procedure was employed for selection of blocks, villages and betel vine growers. Four blocks namely Karimpur 1, Karimpur 2, Krishnaganj and Chakdaha blocks were purposively selected from Nadia district. Eight villages predominated by betel vine growers namely Arabpur, Kechuadanga, Rajapur, Hogolberia, Taldah, Adityapur, Simurali and Anyetpur were selected purposively from four above mentioned blocks. Two hundred betel vine growers from the selected villages were selected randomly. All the extensionists working in the field of betel vine cultivation in the study area form the universe of the study and all the extensionists (25) were selected for the purpose of study. All the researchers (10) related with betel vine cultivation in the study area were interviewed.

Mapping is a very useful tool to draw a comprehensive view of the information system and to analyze the linkage in it. The various actors in the AKIS were contacted and asked to indicate other knowledge agent when they had contacts and their reciprocal links with all other actors. The answer received from the actors about their relation with the other actors was cross checked with the latter. The subject matter content of the information links in both directions and their relative strength (mainly frequency) in both directions were tabulated. The information thus obtained was summarized in the matrix forms. In the matrix, the columns show from where various actors received information and the rows show to whom they gave information. The cells indicated the subject matter area, in which information is transferred and the strength of the link. The mapping of the information linkage matrix to analyze the extent of information exchange between various actors pertaining to different subject matter area was used as a tool to analyze AKIS by Van Beek (1991); Blum (1991); Blum (1996); Blum \& Katz (1997); Gupta (1998) and Saha (2001).

\section{Results and Discussion}

In the AKIS system of Nadia District, nine actors namely Researchers, Extensionists, Opinion Leaders Input dealers, Print Media, Neighbor/ Friend/ Relative, Assistant Director of Agriculture, Horticulture Development Officer, Non govt. Organization/Self Help Group/ Cooperatives, Krishi Projukti Sahaok were identified. Table 1 shows the matrix of linkage among 09 actors with respect to betel vine growers. The columns show from whom the various actors received information and the rows show to whom they deliver information. The cells indicate the subject matter area on which information was transferred and the strength of the link (very strong-5, strong-4, medium-3, weak-2, negligible-1). The subject matter area was cultural practices, pant protection techniques and harvesting of betel vine. In the matrix, betel vine growers were put into centre. It was observed that the betel vine growers received information from nearly all other

Table 1: Linkage matrix with respect to betel vine growers $(n=200)$

\begin{tabular}{|c|c|c|c|c|c|c|c|c|c|c|}
\hline \multirow{2}{*}{$\begin{array}{l}\text { Receives } \\
\text { Knowledge \& } \\
\text { information }\end{array}$} & \multicolumn{10}{|c|}{ Delivers knowledge \& information } \\
\hline & $\begin{array}{c}\text { Re- } \\
\text { searcher }\end{array}$ & $\begin{array}{l}\text { Exten- } \\
\text { sionist }\end{array}$ & PM & $\begin{array}{l}\text { Opinion } \\
\text { leader }\end{array}$ & $\begin{array}{l}\text { Farm- } \\
\text { ers }\end{array}$ & $N / F / R$ & $\begin{array}{l}\text { ADA/ } \\
\text { HDO }\end{array}$ & $\begin{array}{c}\text { Input } \\
\text { Dealers }\end{array}$ & $\begin{array}{c}\text { NGO/ } \\
\text { SHG/Co- } \\
\text { operatives }\end{array}$ & KPS \\
\hline Researcher & $x$ & 4C4P1H & 4C4P1H & $2 \mathrm{C} 2 \mathrm{P} 2 \mathrm{H}$ & 1C1P1H & 1C1P1H & $4 \mathrm{C} 5 \mathrm{P} 3 \mathrm{H}$ & 1C1P1H & $2 \mathrm{C} 2 \mathrm{P} 1 \mathrm{H}$ & $3 \mathrm{C} 3 \mathrm{P} 2 \mathrm{H}$ \\
\hline Extensionist & $4 \mathrm{C} 341 \mathrm{H}$ & X & $3 \mathrm{C} 3 \mathrm{P} 1 \mathrm{H}$ & $5 \mathrm{C} 5 \mathrm{P} 3 \mathrm{H}$ & $5 \mathrm{C} 5 \mathrm{P} 3 \mathrm{H}$ & $3 \mathrm{C} 21 \mathrm{PH}$ & $5 \mathrm{C} 5 \mathrm{P} 4 \mathrm{H}$ & $4 \mathrm{C} 5 \mathrm{P} 2 \mathrm{H}$ & $4 \mathrm{C} 3 \mathrm{P} 2 \mathrm{H}$ & $5 \mathrm{C} 5 \mathrm{P} 3 \mathrm{H}$ \\
\hline Print media & 4C4P1H & 4C4P1H & $x$ & $1 \mathrm{C} 1 \mathrm{P} 1 \mathrm{H}$ & $1 \mathrm{C} 1 \mathrm{P} 1 \mathrm{H}$ & $1 \mathrm{C} 1 \mathrm{P} 1 \mathrm{H}$ & $3 \mathrm{C} 2 \mathrm{P} 1 \mathrm{H}$ & $1 \mathrm{C11PH}$ & $1 \mathrm{C1P} 1 \mathrm{H}$ & $2 \mathrm{C} 2 \mathrm{P} 2 \mathrm{H}$ \\
\hline Opinion leader & $2 \mathrm{C} 3 \mathrm{P} 1 \mathrm{H}$ & $3 \mathrm{C} 32 \mathrm{PH}$ & 1C1P1H & $x$ & $4 \mathrm{C} 5 \mathrm{P} 4 \mathrm{H}$ & $3 \mathrm{C} 3 \mathrm{P} 2 \mathrm{H}$ & 4С5Р3H & $3 \mathrm{C} 5 \mathrm{P} 2 \mathrm{H}$ & $3 \mathrm{C} 4 \mathrm{P} 2 \mathrm{H}$ & $4 \mathrm{C} 5 \mathrm{P} 2 \mathrm{H}$ \\
\hline Farmers & & & & & x & $4 \mathrm{C} 4 \mathrm{P} 2 \mathrm{H}$ & & $4 \mathrm{C} 4 \mathrm{P} 2 \mathrm{H}$ & $3 \mathrm{C} 3 \mathrm{P} 2 \mathrm{H}$ & $4 \mathrm{C} 5 \mathrm{P} 3 \mathrm{H}$ \\
\hline $\begin{array}{l}\mathrm{N} / \text { friend/ rela- } \\
\text { tive }\end{array}$ & $1 \mathrm{C} 1 \mathrm{P} 1 \mathrm{H}$ & $3 \mathrm{C} 2 \mathrm{P} 1 \mathrm{H}$ & 1C1P1H & $3 \mathrm{C} 3 \mathrm{P} 2 \mathrm{H}$ & $4 \mathrm{C} 4 \mathrm{P} 2 \mathrm{H}$ & $x$ & $4 \mathrm{C} 4 \mathrm{P} 2 \mathrm{H}$ & $3 \mathrm{C} 4 \mathrm{P} 1 \mathrm{H}$ & $2 \mathrm{C} 3 \mathrm{P} 1 \mathrm{H}$ & $2 \mathrm{C} 3 \mathrm{P} 1 \mathrm{H}$ \\
\hline ADA/HDO & 4С5Р3Н & $5 \mathrm{C} 5 \mathrm{P} 4 \mathrm{H}$ & $3 \mathrm{C} 4 \mathrm{P} 4 \mathrm{H}$ & 4С5Р3Н & $4 \mathrm{C} 5 \mathrm{P} 2 \mathrm{H}$ & $4 \mathrm{C} 4 \mathrm{P} 2 \mathrm{H}$ & $x$ & $35 \mathrm{CP} 1 \mathrm{H}$ & $3 \mathrm{C} 3 \mathrm{P} 2 \mathrm{H}$ & $5 \mathrm{C} 5 \mathrm{P} 4 \mathrm{H}$ \\
\hline Input dealers & $1 \mathrm{C} 1 \mathrm{P} 1 \mathrm{H}$ & $4 \mathrm{C} 5 \mathrm{P} 2 \mathrm{H}$ & $1 \mathrm{C} 1 \mathrm{P} 1 \mathrm{H}$ & $3 \mathrm{C} 5 \mathrm{P} 2 \mathrm{H}$ & $4 \mathrm{C} 4 \mathrm{P} 2 \mathrm{H}$ & $3 \mathrm{C} 4 \mathrm{P} 1 \mathrm{H}$ & $3 \mathrm{C} 5 \mathrm{P} 1 \mathrm{H}$ & $x$ & $3 \mathrm{C} 4 \mathrm{P} 2 \mathrm{H}$ & $4 \mathrm{C} 5 \mathrm{P} 2 \mathrm{H}$ \\
\hline $\begin{array}{l}\text { NGO/SHG/ co- } \\
\text { operative }\end{array}$ & $2 \mathrm{C} 2 \mathrm{P} 1 \mathrm{H}$ & $4 \mathrm{C} 3 \mathrm{P} 2 \mathrm{H}$ & $1 \mathrm{C} 1 \mathrm{P} 1 \mathrm{H}$ & $3 \mathrm{C} 4 \mathrm{P} 2 \mathrm{H}$ & $3 \mathrm{C} 3 \mathrm{P} 2 \mathrm{H}$ & $2 \mathrm{C} 3 \mathrm{P} 1 \mathrm{H}$ & $3 \mathrm{C} 3 \mathrm{P} 2 \mathrm{H}$ & $3 \mathrm{C} 4 \mathrm{P} 2 \mathrm{H}$ & $x$ & 4С4Р3Н \\
\hline KPS & $3 \mathrm{C} 3 \mathrm{P} 2 \mathrm{H}$ & $5 \mathrm{C} 5 \mathrm{P} 3 \mathrm{H}$ & $2 \mathrm{C} 2 \mathrm{P} 2 \mathrm{H}$ & $4 \mathrm{C} 5 \mathrm{P} 2 \mathrm{H}$ & $4 \mathrm{C} 5 \mathrm{P} 3 \mathrm{H}$ & $2 \mathrm{C} 3 \mathrm{P} 1 \mathrm{H}$ & $5 \mathrm{C} 5 \mathrm{P} 4 \mathrm{H}$ & $4 \mathrm{C} 5 \mathrm{P} 2 \mathrm{H}$ & 4C4P3H & $x$ \\
\hline
\end{tabular}

Strength of link: Very strong-5, strong-4, Medium-3, Weak-2 Negligible-1. Contact area: C-Cultural practices, P-Pant protection, $\mathrm{H}$ - Harvesting Actors: Researcher, Extensionist, Opinion leader Input dealers PM -Print Media, NFR-Neighbor, Friend, Relative, ADA-Assistant Director of Agriculture, HDO- Horticulture Development Officer, NGO/SHG-Non govt. Organization/ Self Help Group, KPS- Krishi Projukti Sahaok 
actors (column-5), but they gave direct feed back to only few (row-5). It is evident from the matrix that direct feedback was almost missing. This may be due to poor user control over technology development. Collaborative efforts by certain organization to organize, mobilize and empower betel vine growers to 'pull down' the goods and services they require, were identified as one of the weakest area in Nadia AKIS. These findings are in lieu with the findings of Gupta (1998) and Saha (2001). Betel vine growers were in close contact with 'Krishi Projukti Sahayak', neighbours, friends and relatives, input dealers and to some extent Non-Government organization and Cooperatives. Most of the betel vine growers used to discuss their problems related to cultural practices, plant protection techniques and harvesting aspect of betel vine cultivation with 'Krishi Projukti Sahaok', neighbors, friends and relatives, input dealers and to some extent Non-Government organization and Cooperatives. 'Krisi Projukti Sahok' is a fully professional change agent of line department of Government of West Bengal who intensively contacts farmers to influence their decision about betel vine cultivation. Not only do they provide contacts with clients but they are also able to bridge the heterophily gap between Assistant Directors of Agriculture and Horticulture Development officers and clients, especially, resource poor and resource medium farmers. Various experts in the field of agriculture in general and betel vine cultivation in particular give them vigorous training and they are responsible to provide door-to-door services to the farmers.

It was evident from the matrix that information flow was linear in majority of the cases. In most of the cases the feedback got blocked with some of the actors as upstream flow of information was weak. It was obvious from the matrix that very weak feedback was reaching at the level of researchers, extensionists, print media and electronic media. This confirms the findings of Gupta (1998) and Saha (2001).

Researchers, extensionists were strongly associated with print media mainly because of publication in research and farm journals and they got feedback via this media by reading extension and other literature. The print media was unable to articulate in the village information systems consisting of betel vine growers along with his neighbors, relatives, friends and input dealers. Gupta (1998) and Pal (1999) also reported this. Weak linkages existed between researchers and extension scientists working in the same institution. Researchers and extension scientists were giving less importance to extension programmes like seminars, trainings, demonstration, campaigns, dairy mela, village level workshops and conferences. Extension workers at district, block and village level were moderately associated with extension programmes. Extension programmes were having a tendency to serve the resource rich farmers. Researchers, extension scientists were unable to maintain frequent direct contact with farmers of all categories. Hence the linkage existed among researchers, extensionists and betel vine growers was negligible.

\section{Conclusion}

Research has impact only if its contributions are utilized by farmers and especially if it focuses on farmers' problem. In the absence of effective linkages, the process of dissemination of innovation is disrupted and the effectiveness of research system and its relevance to farmers is reduced. It was observed that the singularity of AKIS was often missing. Therefore, establishment of institutional framework and development of appropriate linkage strategies and action plans are to be given utmost priority to improve research-users linkages.

\section{References}

Bachhav, N., 2012. "Information Needs of the Rural Farmers": A Study from Maharashtra, India: A Survey, (2012), Library Philosophy and Practice (e-journal), 866.

Blum, A., Katz, M., 1997. The diary knowledge system in Israel. Paper presented in the $13^{\text {th }}$ European Seminar on Extension Education, Dublin, University College,

Blum, A., 1991. what can be learned from a comparison of two agricultural knowledge systems, the case of the Netherlands and Israel. Agriculture Ecosystems and Environments 33, 25-339.

Blum, A., 1996. The agricultural knowledge systems experiences of western european countries. In Drygas, D. et al. (Eds). Agricultural extension as a link of the agricultural knowledge system in the process with European Union Warrow. The ministry of agriculture and food economy and the University of Agriculture in Warsaw.

Cash, D.W., 2001. In order to aid in diffusing useful and practical information: agricultural extension and boundary organizations. Science Technology and Human Values 26, 431-453.

Galloway, L., Mochrie, R., 2005. The use of ICT in rural firms: a policy-orientated literatura review. The Journal of Policy, Regulation and Strategy for Telecommunications 7, 33-46.

Gupta, J., 1998. A study of the information management in diary knowledge information system, Ph.D. thesis. Merut.

Pal, P.P., 1999. Information seeking behaviour of tribal farmers of Meghalaya. Indian Journal of Hill Farming $12,124-125$.

Rao, N.H., 2006. A framework for implementing information and communication technologies in agricultural development in India. Technological Forecasting and Social Change 74, 491-518.

Saha, 2001. An analysis of the dairy knowledge information system in Birbhum, West Bengal. M.Sc. Thesis, NDRI, Karnal, Haryana.

Van Beek, P.G.H., 1991. The Queensland dairy AKIS. Proceeding of European Seminar on knowledge Management and Information Technology, Agril, University, Wageningen. 